\title{
Moving from the terminology debate to a transdisciplinary understanding of the problem
}

\author{
Commentary on: Ten myths about work addiction (Griffiths et al., 2018)
}

\author{
CRISTINA QUINONES*
}

Department of People and Organisations, Open University Business School, Milton Keynes, UK

(Received: September 18, 2018; revised manuscript received: November 7, 2018; accepted: November 17, 2018)

\begin{abstract}
This commentary considers a recent debate paper which presents and counters 10 work addiction myths. I reflect upon the proposal to move the field forward by distinguishing between, work addiction, which denotes a clinical phenomenon; and workaholism, a term used by the occupational psychology literature with little agreement about its defining dimensions beyond working compulsively. Rather than choosing between these two terms, I argue that addiction experts should lead a transdisciplinary integration of findings from studies where participants report both working compulsively and experiencing significant conflict. I also stress the importance of understanding the macro factors underlying this particular addiction.
\end{abstract}

Keywords: work addiction, workaholism, clinical manifestations, critical approach, transdisciplinary

\section{THE TERMINOLOGY DEBATE}

Occupational psychologist have studied people's overengagement with work for some time under the labels of "workaholism," "compulsive work," and to a lesser extent, "work addiction" (e.g., Burke, 2001; Burke \& Ng, 2006; Clark, Michel, Zhdanova, Pui, \& Baltes, 2016; Matuska, 2010; McMillan, O’Driscoll, \& Burke, 2003; Mudrack, 2006; Ng, Sorensen, \& Feldman, 2007; Quinones \& Griffiths, 2015; Quinones, Griffiths, \& Kakabadse, 2016; Schaufeli, Shimazu, \& Taris, 2009; Schaufeli, Taris, \& Bakker, 2006; Taris, Schaufeli, \& Shimazu, 2010; Van den Broeck et al., 2011; Van Wijhe, Peeters, \& Schaufeli, 2014). The rare use of the term addiction in this field seems to be consistent with the fact that despite its negative consequences (e.g., employee burnout, depression, and low productivity; De Carlo et al., 2014; Innanen, Tolvanen, \& Salmela-Aro, 2014; Schaufeli, Bakker, van der Heijden, \& Prins, 2009), studies have also reported links with socially and organizationally valued attitudes and behaviors, such as job satisfaction and job involvement (e.g., Baruch, 2011; $\mathrm{Ng}$ et al., 2007). I agree with Griffiths, Demetrovics, and Atroszko (2018) that the lack of consensus about the number and type of dimensions proposed in the occupational psychology literature is a strong barrier to integrating the findings and advancing our understanding of working compulsively in a way that causes sustained and significant conflict. Hence, other experiences such as working excessively for a limited period of time, or being over involved with one's work, although potentially harming in the long term, may also have valued rewards and does not have the more extreme features and devastating effects of addiction. To sum up, I agree with Griffiths et al. that the "miss-use" of addiction terminology (i.e., work addiction and workaholism) is a strong barrier to the advancement of our understanding about the experience of those actually struggling with work addiction.

The widespread use of this terminology has permeated common language, as the general population often use addiction terms to describe someone working long hours, or being much attached to their work. One of the contributing factors to this popularization can be the short, wide-reaching news articles quoting research findings with "catchy" headlines about workaholics (which I witnessed personally from the way my own research was portrayed in some outlets). More widely, cultural artifacts like Hollywood movies have also contributed to making workaholism somehow "sexy." This is achieved through the combination of socially desirable traits, such as youth, physical attractiveness, and professional ambition of the characters often working in highly regarded sectors, such as law, medicine, or business [e.g., "Up in the air" (2009), "Devil wears Prada" (2006), "The intern" (2015), and "Set it up" (2018)]. The social acceptance of this particular "addiction" as opposed to others can be easily appreciated when thinking about the different reactions friends and family would have to a confession of "I am a workaholic," as opposed to "I am an alcoholic" or even "I am a pathological

* Corresponding address: Cristina Quinones; Department of People and Organisations, Open University Business School, Walton Hall, Milton Keynes, MK7 6AA, UK; Phone: +44 0190863 2763; E-mail: cristina.quinones@open.ac.uk

This is an open-access article distributed under the terms of the Creative Commons Attribution-NonCommercial 4.0 International License, which permits unrestricted use, distribution, and reproduction in any medium for non-commercial purposes, provided the original author and source are credited, a link to the CC License is provided, and changes - if any - are indicated. 
gambler." According to Sussman et al. (2014), workaholism is a "nurturance-type" of addiction; in other words, the addictive behaviors are socially linked to the achievement of financial resources, and in that way it conforms to social expectations about adulthood. In contrast, substance-based addiction, or behavioral addictions such as gambling are perceived to be driven mostly by self-pleasure motives.

I agree with Griffiths et al. (2018) that going back to a clinical characterization of the phenomenon, and a strong effort to differentiate work addiction from other related patterns of attitudes and behaviors about some people's engagement with work is necessary. In fact, recent metaanalysis and previous theoretical reviews have led many to agree that an addiction-based explanation of workaholism appears the most sensible approach to understand this phenomenon (Clark et al., 2016; Griffiths, 2011; Griffiths \& Karanika-Murray, 2012; Griffiths et al., 2018; Shimazu, Schaufeli, Kamiyama, \& Kawakami, 2015). However, I do question the proposal of solving this problem through the term "work addiction" to study clinical manifestations of the behavioral addiction, and using term "workaholism" for all other conceptualizations from the occupational psychology literature.

I believe that the problem with workaholism is not the term itself, but the conceptual chaos that causes the lack of agreement about its key dimensions (Andreassen, 2014; $\mathrm{Ng}$ et al., 2007). Hence, removing the use "workaholism" is unnecessary, and would stop us from crediting the author Oates, who coined this term after identifying similar cognitive-behavioral patterns as those present in "alcoholism." In fact, the author conceptualized workaholism in the same as the component model of addiction, which has been extensively validated across different addictions (Griffiths, 2005, 2011; Andreassen, Griffiths, Hetland, \& Pallesen, 2012). Thus, according to Oates, a workaholic is

“... a person whose need for work has become so excessive that it creates noticeable disturbance or interference with his bodily health, personal happiness, and interpersonal relations, and with his smooth social functioning" (Oates, 1971, p. 4).

Furthermore, considering that public impact should be at the heart of what we do as scholars, I believe it is important that we work with society educating about different addictions using the vocabulary they already are familiar with. The wider population is aware about the highly damaging effects of having an addiction to alcohol and they know it as "alcoholism." Hence, they can also learn and become aware of the harm that a specific pattern of compulsive work associated with conflict and loss of control can cause, regardless of whether this is referred to as workaholism or work addiction. However, I do believe that we need to work with the academic community to restrict the use of these two terms to situations when we are examining participants who exhibit the clinical manifestations of the problem. Hence, the "good versus bad workaholic" should be replaced by different labels at least academically in a similar way that we would not expect to find an academic classification about "a good versus bad alcoholic type."
The article also suggests moving the literature forward by either focusing on psychological addiction literature or a transdisciplinary approach. I believe the first suggestion would leave out the extensive and important work carried out from occupational psychologists for instance on the conditions that maintain and reinforce the problem (e.g., Schaufeli et al., 2006; Schaufeli, Bakker, et al., 2009; Schaufeli, Shimazu, et al., 2009; Taris et al., 2010). Many of us have been trained in different psychological fields; therefore, the insights that can be achieved from collaboration across psychological disciplines should not be underestimated. Furthermore, there are areas of debate within the addictions literature itself, which may benefit from the input of different fields. For instance, in spite of the strong consensus about the validity of the component model of addictions, this has been criticized for emphasizing symptom-focused interventions rather than those who could treat the underlying psychological problems (Billieux et al., 2015). In view of this, I advocate Griffiths et al.'s (2018) alternative proposal of focusing on working transdisciplinary. Notwithstanding, I believe that behavioral and general addiction experts should be the driving force leading a thorough review of how different disciplines have studied workaholism, compulsive work, and work addiction, through the organization of expert symposiums and oral and written debates. This could help in the ultimate aim of effectively integrating the findings from the different disciplines when these studies fit the definition of addiction (as opposed to other phenomena).

\section{CONTEXT MATTERS}

In the debate paper, the authors comment briefly on the importance of contextual factors contributing to work addiction. Previously, Sussman, Lisha, and Griffiths (2011) argued that lifestyle and type of social learning from our environment have as much explanatory value (or more) in workaholism than personal vulnerabilities. Nonetheless, as psychologists, we tend to focus on the individual and close relationship levels when characterizing and working on prevention and treatment of these addictions. Critical psychologists have long argued for a thorough consideration of the social determinants of addiction contributing to the etiology and maintenance of the problem (e.g., poverty, weak social support, exclusion, unemployment, hyperindividualism, etc.). Isolating the addiction from these factors shifts responsibility onto "addicts" and their support networks (Reinarman \& Granfield, 2015; Van der Linden, 2015), while leaving the social structures that support it untouched (Reinarman \& Granfield, 2015; Suissa, 2014). Workaholism is a strong example of an addiction that could not be understood without the socioeconomic context in which it emerges, as it would be difficult to imagine a work addict in a non-capitalist society.

The idea of "loss of control" is central to disease theories of addiction (Reinerman \& Granfield, 2015; Van der Linden, 2015), and it is one of the core symptoms in the components model of addiction (and related biological models). A critical and contextualized approach to addiction 
also focuses on "loss of control" to explain addiction although from a different angle. Loss of control here is explained by the inherent conflict in contemporary society about encouraging and penalizing consumption. We are surrounded by easy access, fast, frequent (though often short-lived) sources of pleasure, and gratification enveloped in well-designed marketing strategies. Yet, this society also bombards individuals with the idea of taking responsibility, and to exert self-control. When it comes to work addiction, the ability to connect $24 / 7$ has also become a major threat to those vulnerable to work compulsively (Quinones, 2017). Our ability to work transdisciplinary (not only with occupational, but also with critical psychologists, social theorists, and sociologists) will help us better understand and potentially challenge these wider social and economic factors in order to jointly promote more sustainable work patterns and prevent workaholism.

\section{Conclusions}

In this commentary, I assessed one of Griffiths et al.'s proposals to move forward the field by distinguishing between "work addiction" and "workaholism." Since both refer more socially to addiction, I argue that the focus should be on restricting the use of these two terms to describe and study and describe the clinical manifestations of the problem. I also commented not only on the need to work transdisciplinary, but also working beyond the psychology field, to address our bias toward treatment and prevention at the individual level and challenge the social, cultural, and political triggers that sustain unhealthy working ways.

\section{Funding sources: None.}

Author's contribution: $\mathrm{CQ}$ is the sole author of this "Commentary" article and responsible for the submission of final version of the manuscript.

Conflict of interest: The author declares no conflict of interest.

\section{REFERENCES}

Andreassen, C. S. (2014). Workaholism: An overview and current status of the research. Journal of Behavioural Addictions, 3(1), 1-11. doi:10.1556/JBA.2.2013.017

Andreassen, C. S., Griffiths, M. D., Hetland, J., \& Pallesen, S. (2012). Development of a Work Addiction Scale. Scandinavian Journal of Psychology, 53(3), 265-265. doi:10.1111/ j.1467-9450.2012.00947.x

Baruch, Y. (2011). The positive wellbeing aspects of workaholism in cross cultural perspective: The chocoholism metaphor. Career Development International, 16(6), 572-591. doi: $10.1108 / 13620431111178335$

Burke, R. J. (2001). Workaholism in organizations: The role of organizational values. Personnel Review, 30(6), 637-645. doi:10.1108/EUM0000000005977
Burke, R. J., \& Ng, E. S. W. (2006). Workaholic behaviors: Do colleagues agree? International Journal of Stress Management, 14(3), 312-320. doi:10.1037/1072-5245.14.3.312

Billieux, J., Philippot, P., Schmid, C., Maurage, P., De Mol, J., \& Van der Linden, M. (2015). Is dysfunctional use of the mobile phone a behavioural addiction? Confronting symptom-based versus process-based approaches. Clinical Psychology and Psychotherapy, 22(5), 460-468. doi:10.1002/cpp.1910

Clark, M. A., Michel, J. S., Zhdanova, L., Pui, S. Y., \& Baltes, B. B. (2016). All work and no play? A meta-analytic examination of the correlates and outcomes of workaholism. Journal of Management, 42(7), 1836-1873. doi:10.1177/0149206314 522301

De Carlo, N. A., Falco, A., Pierro, A., Dugas, M., Kruglanski, A. W., \& Higgins, E. T. (2014). Regulatory mode orientations and well-being in an organizational setting: The differential mediating roles of workaholism and work engagement. Journal of Applied Social Psychology, 44(11), 725-738. doi:10.1111/jasp. 12263

Griffiths, M. D. (2005). A components model of addiction within a biopsychological framework. Journal of Substance Use, 10(4), 191-197. doi:10.1080/14659890500114359

Griffiths, M. D. (2011). Workaholism: A 21st century addiction. The Psychologist: Bulletin of the British Psychological Society, 24, 740-744. Retrieved from https://thepsychologist.bps. org.uk/volume-24/edition-10/workaholism-\%E2\%80\%93-21stcentury-addiction

Griffiths, M. D., Demetrovics, Z., \& Atroszko, P. A. (2018). Ten myths about work addiction. Journal of Behavioral Addictions. Advance online publication. doi:10.1556/2006.7. 2018.05

Griffiths, M. D., \& Karanika-Murray, M. (2012). Contextualising over-engagement in work: Towards a more global understanding of workaholism as an addiction. Journal of Behavioral Addictions, 1(3), 87-95. doi:10.1556/JBA.1. 2012.002

Innanen, H., Tolvanen, A., \& Salmela-Aro, K. (2014). Burnout, work engagement and workaholism among highly educated employees: Profiles, antecedents and outcomes. Burnout Research, 1(1), 38-49. doi:10.1016/j.burn.2014.04.001

Matuska, K. M. (2010). Workaholism, life balance, and well-being: A comparative analysis. Journal of Occupational Science, 17(2), 104-111. doi:10.1080/14427591.2010.9686681

McMillan, L. H. W., O’Driscoll, M. P., \& Burke, R. J. (2003). Workaholism: A review of theory, research, and future directions. In C. L. Cooper \& I. T. Robertson (Eds.), International review of industrial and organizational psychology (Vol. 18, pp. 167-189). New York, NY: Wiley.

Mudrack, P. E. (2006). Understanding workaholism: The case for behavioral tendencies. In R. J. Burke (Ed.), Research companion to working time and work addiction (pp. 108-128). Northapton, MA: Edward Elgar Publishing.

Ng, T. W. H., Sorensen, K. L., \& Feldman, D. C. (2007). Dimensions, antecedents, and consequences of workaholism: A conceptual integration and extension. Journal of Organizational Behavior, 28(1), 111-136. doi:10.1002/job.424

Oates, W. (1971). Confessions of a workaholic: The facts about work addiction. New York, NY: World Publishing Co.

Quinones, C. (2017). Does intense ICT use after work help or hinder psychological recovery? CIPD Applied Research Conference 2016: The shifting landscape of work and 
working lives (Conference paper number: CIPD/ARC/2016/1). Retrieved from https://www.cipd.co.uk/learn/events-networks/ applied-research-conference

Quinones, C., \& Griffiths, M. (2015). Addiction to work: A critical review of the workaholism construct and recommendations for assessment. Journal of Psychiatric Nursing, 53(10), 48-59. doi:10.3928/02793695-20150923-04

Quinones, C., Griffiths, M., \& Kakabadse, N. (2016). Compulsive Internet use and workaholism: An exploratory two-wave longitudinal study. Computers in Human Behaviour, 60, 492-499. doi:10.1016/j.chb.2016.02.060

Reinarman, C., \& Granfield, R. (2015). Addiction is not just a brain disease: Critical studies of addiction. In R. Granfield \& C. Reinarman (Eds.), Expanding addictions: Critical essays (pp. 1-21). New York, NY: Routledge.

Schaufeli, W. B., Bakker, A. B., van der Heijden, F. M. M. A., \& Prins, J. T. (2009). Workaholism, burnout and well-being among junior doctors: The mediating role of role conflict. Work \& Stress, 23(2), 155-172. doi:10.1080/02678370902834021

Schaufeli, W. B., Shimazu, A., \& Taris, T. W. (2009). Being driven to work excessively hard: The evaluation of a two-factor measure of workaholism in the Netherlands and Japan. Cross-Cultural Research, 43(4), 320-348. doi:10.1177/1069397109337239

Schaufeli, W. B., Taris, T. W., \& Bakker, A. (2006). Dr. Jekyll and Mr. Hide: On the differences between work engagement and workaholism. In R. Burke (Ed.), Research companion to working time and work addiction (pp. 193-217). Northampton, MA: Edward Elgar.

Shimazu, A., Schaufeli, W. B., Kamiyama, K., \& Kawakami, N. (2015). Workaholism vs. work engagement: The two different predictors of future well-being and performance. International Journal of Behavioral Medicine, 22(1), 18-23. doi:10.1007/ s12529-014-9410-x
Suissa, A. J. (2014). Cyberaddictions: Toward a psychosocial perspective. Addictive Behaviors, 39(12), 1914-1918. doi:10.1016/ j.addbeh.2014.07.027

Sussman, S., Arpawong, T. E. M., Sun, P., Tsai, J., Rohrbach, L. A., \& Sprutjt-Metz, D. (2014). Prevalence and co-occurrence of addictive behaviors among former alternative high school youth. Journal of Behavioral Addictions, 3(1), 33-40. doi:10.1556/JBA.3.2014.005

Sussman, S., Lisha, N., \& Griffiths, M. (2011). Prevalence of the addictions: A problem of the majority or the minority? Evaluation and the Health Professions, 34(1), 3-56. doi:10.1177/0163278710380124

Taris, T. W., Schaufeli, W., \& Shimazu, A. (2010). The push and pull of work: The difference between workaholism and work engagement. In A. B. Bakker \& M. P. Leiter (Eds.), Work engagement: A handbook of essential theory and research (pp. 39-53). Hove, UK: Psychological Press.

Van den Broeck, A., Schreurs, B., De Witte, H., Vansteenkiste, M., Germeys, F., \& Schaufeli, W. (2011). Understanding workaholics' motivations: A self-determination perspective. Applied Psychology, 60(4), 600-621. doi:10.1111/j.14640597.2011.00449.x

Van Der Linden, M. (2015). Commentary on: Are we overpathologizing everyday life? A tenable blueprint for behavioral addiction research: Addictions as a psychosocial and cultural construction. Journal of Behavioral Addictions, 4(3), 145-147. doi:10.1556/2006.4.2015.025

Van Wijhe, C. I., Peeters, M. C., \& Schaufeli, W. B. (2014). Enough is enough: Cognitive antecedents of workaholism and its aftermath. Human Resource Management, 53(1), 157-177. doi:10.1002/hrm. 21573 